\title{
Przesłanie szesnastego Międzynarodowego Biennale Architektury w Wenecji w 2018 roku na tle przesłania innych edycji
}

\author{
Hubert Trammer \\ https://orcid.org/0000-0001-8885-4323 \\ huberttrammer@wp.pl \\ Katedra Architektury, Urbanistyki i Planowania Przestrzennego, \\ Wydziat Budownictwa i Architektury, Politechnika Lubelska
}

\begin{abstract}
Streszczenie: Szesnaste Międzynarodowe Biennale Architektury, odbyło się w Wenecji w 2018 roku pod tytułem Freespace. Kuratorki w odróżnieniu od kuratorów większości edycji zrezygnowały z sięgania po wielką narrację, lecz skierowały uwagę ku podstawowym (codziennym) wartościom jakie może dać architektura. Niestety refleksja kuratorek poszła w stronę przypominającą promocyjne teksty towarzyszące inwestycjom. Nasuwa się pytanie na ile możliwa jest przekonywująca i głęboka refleksja o podstawowych wartościach związanych z architekturą.
\end{abstract}

Słowa kluczowe: Międzynarodowe Biennale Architektury w Wenecji, La Biennale di Venezia, Mostra Internazionale di Architettura, Freespace, refleksja architektoniczna, myśl architektoniczna

\section{Wprowadzenie}

Międzynarodowe Biennale Architektury w Wenecji jest w Polsce uważane za najważniejsze wydarzenie architektoniczne na świecie 1 . Można się zastanawiać czy jest to słuszna opinia, czy donioślejsze nie są Kongresy Międzynarodowej Unii Architektów UIA. Jednakże z pewnością Międzynarodowe Biennale Architektury w Wenecji przyciąga rzesze architektów i osób zainteresowanych architekturą z całego świata, w tym najbardziej znanych architektów i odbija się szerokim echem w świecie. Ostatnia edycja, która odbyła się w 2018 roku po raz kolejny wiązała się z rekordem liczby odwiedzających, których było ponad 275 tysięcy i dodatkowo 14434 podczas kilkudniowego udostępnienia wystaw Biennale dla wybranych osób przed otwarciem². Forma wystawy o długim czasie trwania pozwala na przyswojenie znacznie większej ilości treści, niż w przypadku kongresów złożonych z szeregu równoległych sesji. Nie ulega też wątpliwości że prestiż Międzynarodowego Biennale Architektury w Wenecji jest bardzo duży. Stąd też dla wielu osób zaskakująca jest dość świeża geneza weneckiego Biennale Architektury. O ile Międzynarodowe Biennale Sztuki odbywa się w Wenecji od roku 1895, powiązany z nim instytucjonalnie festiwal filmowy od roku 1932 to pierwsze Międzynarodowe Biennale Architektury odbyło się w Wenecji dopiero w roku $1980^{3}$. 


\section{Charakter i tematyka poszczególnych edycji Międzynarodowego Biennale Architektury w Wenecji}

La Biennale di Venezia (w dosłownym przekładzie Biennale Weneckie) to nazwa instytucji organizującej wydarzenia z dziedzin sztuki, architektury, kina, tańca, muzyki i teatru, oraz prowadzącej archiwa historyczne dotyczące tych dziedzin. Organizuje ona między innymi słynny wenecki festiwal filmowy. Międzynarodowe Biennale Sztuki i Międzynarodowe Biennale Architektury są też określane jako Międzynarodowa Wystawa Sztuki (Esposizione Internazionale d'Arte / International Art Exhibition) i Międzynarodowa Wystawa Architektury (Mostra Internazionale di Architettura / International Architecture Exhibition) w szczególności kiedy nazwy te są prezentowane wraz z nazwą i logo La Biennale di Venezia. Włoskie słowo mostra oznacza wystawę lub pokaz, zaś słowo esposizione - wystawa lub ekspozycja.

Za pierwsze Międzynarodowe Biennale Architektury uważa się wystawę, która odbyła się w 1980 roku pod tytułem La Presenza del Passato, czyli Obecność przeszłości. Jednakże do historii Biennale Architektury zaliczane są też wystawy zorganizowane w latach 1975, 1976 i 1978 roku, których kuratorem był Vittorio Gregotti. Przy tym wystawa w roku 1975 jest określana jako Biennale di Architettura Anni Zero - czyli Biennale Architektury Rok Zerowy. Te wystawy, podobnie jak druga, trzecia i czwarta edycja prezentacji liczonych jako właściwe Biennale Architektury miały bardzo konkretnie określone tematy. Tytuł pierwszego Biennale był mniej konkretny, ale zawartość już dużo bardziej - dotyczyła postmodernizmu. Głównym elementem ekspozycji było 20 modeli fasad autorstwa zaproszonych architektów, które tworzyły postmodernistyczną uliczkę ${ }^{4}$. Generalnie jednak można stwierdzić, że zarówno sam tytuł Obecność przeszłości jak i temat posmodernizmu ma szeroki wymiar uniwersalnej refleksji.

Począwszy od piątej edycji na wzór Międzynarodowego Biennale Sztuki oprócz wystaw kuratorskich na Międzynarodowe Biennale Architektury składają się też wystawy poszczególnych krajów organizowane w ich pawilonach. Ma to związek z tym, że począwszy od piątej edycji Biennale Architektury odbywa się ono w innych latach niż Biennale Sztuki.

Poszczególne kraje przygotowujące własne ekspozycje mają w tym zakresie autonomię. Przy tym duża część ekspozycji nawiązuje do nakreślonych przez kuratorów całego biennale tematów przewodnich.

Tabela 1. Terminy, tematy i kuratorzy poszczególnych edycji Międzynarodowego Biennale Architektury

$\begin{array}{ccc}\begin{array}{c}\text { kolejne Biennale } \\ \text { Architektury }\end{array} & \text { termin } & \text { kurator pochodzenia kuratora }\end{array}$

tytuł edycji (po włosku, angielsku i tłumaczenie na polski)

127 lipca - 20 października $1980 \quad$ Paolo Portogesi Włochy

La Presenza del Passato / The presence of the past/ Obecność przeszłości

20 listopada 1982 - 6 stycznia $1983 \quad$ Paolo Portogesi Włochy

Architettura nei Paesi islamici/ Architecture in Islamic Countries/ Architektura w krajach islamskich

320 lipca - 29 września $1985 \quad$ Aldo Rossi Włochy

Progetto Venezia/ Project Venice / Projekt Wenecja

418 lipca - 28 września $1986 \quad$ Aldo Rossi Włochy

Hedrik Petrus Berlage. Disegni/ Hedrik Petrus Berlage - Drawings / Hendrik Petrus Berlage. Rysunki

58 września - 6 października $1991 \quad$ Francesco Dal Co Włochy

bez tytułu ${ }^{5}$

4 https://www.labiennale.org/en/history-biennale-architettura.

5 Piąta edycja Biennale Architektury była pierwszą w której na wzór Biennale Sztuki zaproszono poszczególne kraje do przedstawienia własnych wystaw w swoich pawilonach (https://www.labiennale.org/en/history-biennale-architettura). Na oficjalnej stronie internetowej Biennale nie jest podawany jego tytuł. Strona internetowa ArchDaily jako tytuł Biennale podaje Forty Architects for the 90s czyli temat wystawy kuratorskiej prezentującej czterdziestu włoskich architektów (https://www.archdaily.com/267113/a-history-of-the-venice-architecture-biennale) 

6
15 września-17 listopada 1996
Hans Hollein
Austria

Sensori del futuro. L'architetto come sismografo /Sensing the Future-The Architect as Seismograph/ Przeczuwanie przyszłości. Architekt jako sejsmograf.

\begin{tabular}{|c|c|c|c|}
\hline 7 & 18 czerwca - 29 października 2000 & Massimiliano Fuksas & Włochy \\
\hline \multicolumn{4}{|c|}{ Less Aesthetics, More Ethics ${ }^{6}$ /Less Aesthetics, More Ethics/Mniej estetyki, więcej etyki. } \\
\hline 8 & 8 września - 3 listopada 2002 & Deyan Sudjic & Wielka Brytania \\
\hline \multicolumn{4}{|c|}{ NEXT ${ }^{7}$ (Następne, najbliższe) } \\
\hline 9 & 12 września - 7 listopada 2004 & Kurt Forster & Szwajcaria \\
\hline \multicolumn{4}{|c|}{ METAMORPH } \\
\hline 10 & 12 września - 7 listopada 2006 & Richard Burdett & Wielka Brytania \\
\hline \multicolumn{4}{|c|}{ Città. Architettura e società /Cities, architecture and society/ Miasto. Architektura i społeczeństwo } \\
\hline 11 & 14 września - 23 listopada 2008 & Aaron Betsky & Stany Zjednoczone Ameryki Północnej ${ }^{8}$ \\
\hline \multicolumn{4}{|c|}{ Out There: Architecture Beyond Building ${ }^{9}$ (Tam poza. Architektura poza budowaniem) } \\
\hline 12 & 22 sierpnia - 22 listopada 2010 & Kazuyo Sejima & Japonia \\
\hline \multicolumn{4}{|c|}{ People meet in architecture ${ }^{10}$ (Architektura łączy ludzi) } \\
\hline 13 & 29 sierpnia - 25 listopada 2012 & David Chipperfield & Wielka Brytania \\
\hline \multicolumn{4}{|c|}{ Common Ground ${ }^{11}$ (wspólny grunt/ wspólna przestrzeń/wspólny mianownik) } \\
\hline 14 & 7 czerwca - 23 listopada 2014 & Rem Koolhaas & Holandia \\
\hline \multicolumn{4}{|c|}{ Fundamentals ${ }^{12}$ (Podstawy) } \\
\hline 15 & 28 maja - 27 listopada 2016 & Alejandro Aravena & Chile \\
\hline \multicolumn{4}{|c|}{ Reporting from the Front ${ }^{13}$ (Donosząc $z$ frontu) } \\
\hline 16 & 26 maja - 25 listopada 2018 & $\begin{array}{c}\text { Yvonne Farrell, Shelley } \\
\text { McNamara }\end{array}$ & Irlandia \\
\hline \multicolumn{4}{|c|}{ Freespace $^{14}$ (Wolna przestrzeń) } \\
\hline 17 & Obecnie planowane na rok $2021^{15}$ & Hashim Sarkis & Liban $^{16}$ \\
\hline
\end{tabular}

How will we live together ${ }^{17}$ (Jak będziemy żyć razem?)

6 W języku włoskim używany był i jest tytuł angielski.

7 W języku włoskim używany był i jest tytuł angielski.

8 Aaron Betsky jako dziecko wyjechał z rodzicami do Holandii i pozostał tam do czasu studiów. W latach $2001-2006$ był dyrektorem Holenderskiego Instytutu Architektury (https://en.wikipedia.org/wiki/Aaron_Betsky).

9 W języku włoskim używany był i jest tytuł angielski.

10 W języku włoskim używany był i jest tytuł angielski.

11 W języku włoskim używany był i jest tytuł angielski.

12 W języku włoskim używany był i jest tytuł angielski.

13 W języku włoskim używany był i jest tytuł angielski.

14 W języku włoskim używany był i jest tytuł angielski.

15 Pierwotnie 17 Międzynarodowe Biennale Architektury miało się odbyć w terminie od 23 maja do 29 listopada 2020 roku, następnie na początku marca 2020 ze względu na pandemię koronawirusa czas trwania został skrócony do terminu 29 sierpnia - 29 listopada 2020 roku, a następnie w maju 2020 roku podano nowy termin od 22 maja do 21 listopada 2021 roku - źródło: inormacje biura prasowego Biennale w Wenecji. Ze względu na nieznany dalszy rozwój sytuacji pandemicznej nie można wykluczyć dalszych przesunięć terminu.

16 Hashim Sarkis studiował i naucza w Stanach Zjednoczonych Ameryki Północnej. Od 1998 roku prowadzi pracownię z biurami w amerykańskim Cambridge i w Bejrucie https://en.wikipedia.org/wiki/Hashim_Sarkis.

17 W języku włoskim używany był i jest tytuł angielski. 
Począwszy od szóstej edycji za każdym razem Biennale posiada przewodni tytuł, który ma skłaniać do refleksji. Każdorazowo temat ma swoje rozwinięcie w postaci wywodu kuratorskiego. Większość tematów tworzyło tak zwane wielkie narracje. Kuratorowane przez Rema Koolhaasa z zespołem czternaste Biennale, które odbyło się w roku 2014 zostało zatytułowane Fundamentals co można przetłumaczyć jako podstawy. Poszczególne kraje zostały poproszone o interpretacje tematu Absorbing modernity 1914-2014 (co można przetłumaczyć jako Przyjmując nowoczesność 1914-2014). Można tu odnaleźć relację z tematem pierwszego Biennale (Obecność przeszłości). Tylko tym razem tematem był nie postmodernizm, a modernizm, a głównym punktem odniesienia nie miejsce historii w teraźniejszości i przeszłości, a stuletni proces historyczny. Tematyka ta, w większości w bardzo interesujący sposób, została uczyniona przedmiotem prezentacji poszczególnych krajów, które pokazały poszczególne epizody czy aspekty czynienia nowoczesności elementem ich architektury ${ }^{18}$.

Kurator odbywającej się w 2016 roku pod tytułem Reporting from the Front, (co można przetłumaczyć jako Donosząc z frontu) piętnastej edycji Biennale Alejandro Aravena zwrócił uwagę na architekturę zaangażowaną społecznie i jednocześnie na wartość jaką ma rozwiązywanie problemów prostymi, adekwatnymi do lokalnych uwarunkowań środkami ${ }^{19}$.

Hashim Sarkis - kurator planowanego pierwotnie na rok 2020, a obecnie na rok 2021 siedemnastego Biennale Architektury pod tytułem How will we live together? kieruje refleksję na kwestię tego jak architektura może sprzyjać tworzeniu wspólnoty. W swoim wywodzie kuratorskim zwraca uwagę na społeczny i polityczny wymiar architektury ${ }^{20}$.

Także kontestujący rozumienie architektury jako nierozerwalnie związanej z budowaniem i określający budynki jako groby architektury, Aaron Betsky, kurator jedenastego biennale architektury zatytułowanego Out There: Architecture Beyond Building ${ }^{21}$ wpisywał się w dominujący trend wielkich narracji i wielkich refleksji.

Nawet tematom pierwszych edycji biennale dotykającym wąsko określonych tematów nie można odmówić głębszej refleksji i szerszej narracji dotyczącej architektury.

Wyjątek stanowiły dwie edycje, których kuratorki odeszły od wielkich narracji ku podstawowemu wymiarowi architektury. Kuratorka dwunastego Biennale Kazuyo Sejima poprosiła 44 pracownie architektoniczne o zinterpretowanie tematu People meet in architecture ${ }^{22}$ co w dosłownym przekładzie znaczy Ludzie spotykaja się $w$ architekturze, ale bardziej oddającym znaczenie tłumaczeniem wydaje się Architektura tączy ludzi. Ten mający dość duży potencjał temat, mogący być może także stać się pretekstem do głębszej narracji lub głębszej refleksji, niestety bez szerszego kuratorskiego poprowadzenia, ale poprzez proste zaproszenie architektów stał podstawą do powstania zbioru autopromocyjnych prezentacji.

Podobny efekt, ale tym razem nie w wyniku rodzaju kuratorskiej abdykacji, ale podejścia kuratorskiego miał miejsce w przypadku szesnastego Międzynarodowego Biennale Architektury.

\section{Szesnaste Międzynarodowego Biennale Architektury w Wenecji w 2018 roku i jego przesłanie}

Kuratorki szesnastego Międzynarodowego Biennale Architektury w Wenecji Yvonne Farrell, Shelley McNamara nadały mu tytuł Freespace, który korzysta z wieloznaczności słowa free w języku angielskim, które oznacza zarówno wolna, dostępna bezpłatna jak i otwarta. Ta wieloznaczność występuje w wielu językach. Przy tym na przykład w języku polskim wolna przestrzeń znaczy też przestrzeń otwarta, dostępna ale już znaczenie bezpłatna przestrzeń nie występuje. Słowo wolny w tym znaczeniu ograniczone jest tylko do zwrotu wstęp wolny. Tytuł Freespace miał w sobie bardzo duży potencjał refleksji na temat dostępności i zamkniętości w architekturze, jej ekskluzywności i inkluzywności. Niestety kuratorki w swoim wywodzie nazwanym manifestem zaprezentowały rozumienie tematu jako afirmację hojności architektury, która jest w stanie dawać przestrzenne prezenty ${ }^{23}$.

\footnotetext{
18 Fundamentals catalogue 2014, s. 20-186.

19 Reporting from the Front 2016, s.19-88.

20 https://www.labiennale.org/en/architecture/2021/17th-exhibition.

21 https://www.labiennale.org/en/history-biennale-architettura.

22 https://www.labiennale.org/en/history-biennale-architettura.

23 Freespace 2018, s. 35.
} 
Przesłanie to niestety w bardzo wielkim stopniu przypomina teksty jakimi architekci tłumaczą, a często usprawiedliwiają swoje projekty i realizacje. Teksty te często mają na celu odwrócenie uwagi od problemów, które z tymi realizacjami się wiążą, a najczęściej służą promocji inwestycji i stojących za nimi architektów. Oczywiście nie można odmówić kuratorkom prawa do optymistycznej refleksji. Jednakże jak pokazała poprzednia edycja weneckiego Biennale optymizm nie musi oznaczać spłycenia refleksji, co niestety w przypadku szesnastej edycji Biennale miało miejsce. Na szczęście wśród zaprezentowanych przez kuratorki przykładów architektury znalazło się wiele takich, które są przykładem tego że temat może być rozumiany głębiej. Były jednak niestety wśród nich też takie, którym można zarzucić płytkie podejście i typową dla architektów autopromocyjność ${ }^{24}$. Także wiele spośród ekspozycji poszczególnych krajów ${ }^{25}$ podeszło do tematu w wartościowy sposób. Jednakże w większości przypadków miało to związek z sięgnięciem po tematykę odnoszącą się do tematów społecznych i politycznych, a więc odrywających się od podstawowego prostego rozumienia architektury, które przedstawiły kuratorki. Całemu Biennale nie udało się osiągnąć spójności i głębi przesłania, którą miała większość spośród wcześniejszych edycji.

\section{Zakończenie}

Słabość przesłania szesnastego Biennale Architektury, podobnie zresztą jak słabość przesłania dwunastego Biennale, którego kuratorką była Kazuyo Sejima każą zadać pytanie czy da się w przekonywujący sposób poruszać kwestii podstawowych wartości architektury. Wątpliwości w tej kwestii wzmacnia doświadczenie czternastego Biennale. Rem Koolhaas i jego zespół doprowadzili wówczas do złożenia się prezentacji poszczególnych krajów w przekonywującą i spójną narrację na temat doświadczenia modernizmu. Kuratorska wystawa Monditalia poświęcona przez działający pod kierunkiem Koolhaasa zespół przykładom architektury z Włoch zestawionym z wybranymi włoskimi filmami ${ }^{26}$ wyszła bardzo przekonywująco. Druga przygotowana przez zespół Koolhaasa wystawa Elements of architecture (Elementy architektury) złożona została z części poświęconych poszczególnych elementów budynków tworzących ich architekturę - sufitowi, fasadzie, oknu, korytarzowi, dachowi, ścianie podłodze, balkonowi, palenisku-ogrzewaniu, toalecie, schodom, schodom ruchomym, windzie, rampie. Wystawa przedstawiała bardzo wiele przykładów, w tym artefaktów. Wyszła jednak bardzo nieprzekonywująco. Miała może wartość inspiracyjną ale refleksja była zaskakująco powierzchowna jak na Biennale Architektury.

Jednocześnie warto zwrócić uwagę na to że fakt, iż to że obydwie edycje Biennale kuratorowane przez kobiety wyszły słabiej niż inne, nie powinien skłaniać do myśli że to kwestia płci. Chociażby poziom refleksji zawartych w każdej wypowiedzi Anne Lacaton pozwala mieć pewność, że kuratorowane przez nią Biennale byłoby jednym z najciekawszych. Być może także wówczas gdyby poruszała ona temat dotyczący podstawowych wartości architektonicznych, który nie sięgałby po głębsze narracje.

\section{Piśmiennictwo}

[1] Fundamentals catalogue 2014, Marsilio/Fondazione la Biennale di Venezia, Wenecja 2014.

[2] Reporting from the Front 2016. Biennale Architettura 2016, Marsilio/Fondazione la Biennale di Venezia, Wenecja 2016.

[3] Freespace 2018. Biennale Architettura 2018. Short Guide, la Biennale di Venezia, Wenecja 2018. 


\section{The Message of the $16^{\text {th }}$ Venice Biennale of Architecture 2018 Freespace compared to the message of the other editions}

Abstract: The $16^{\text {th }}$ International Architecture Biennale took place in Venice in 2018 under the title Freespace. Unlike the curators of most editions, its curators abandoned the great narration, but focused attention on the fundamental (daily) values that the architecture could bring. Unfortunately, the reflection of the curators has gone toward a promotional text accompanying investments. The question arises as to how convincing and deep reflection is possible on the fundamental values of architecture.

Keywords: Venice Biennale of Architecture, La Biennale di Venezia, Freespace, Mostra Internazionale di Architettura, International Architecture Exhibition, architectural reflection 